\title{
Journal of the Canadian Historical Association
}

Revue de la Société historique du Canada

\section{Abstracts/Résumés \\ Résumés}

Volume 8, numéro 1, 1997

URI : https://id.erudit.org/iderudit/031126ar

DOI : https://doi.org/10.7202/031126ar

Aller au sommaire du numéro

Éditeur(s)

The Canadian Historical Association/La Société historique du Canada

ISSN

0847-4478 (imprimé)

1712-6274 (numérique)

Découvrir la revue

Citer ce document

(1997). Abstracts/Résumés. Journal of the Canadian Historical Association /

Revue de la Société historique du Canada, 8(1), 283-293.

https://doi.org/10.7202/031126ar d'utilisation que vous pouvez consulter en ligne.

https://apropos.erudit.org/fr/usagers/politique-dutilisation/ 


\section{Abstracts Résumés}

\section{PRESIDENTIAL ADDRESS DISCOURS DU PRÉSIDENT}

\section{The Invisible Historian}

\section{J.R. MILLER}

Although contemporary events have made it appear that there is widespread support in Canada for history as a discipline, the reality is otherwise. Many individuals, interest groups, and even institutions make considerable use of historical arguments in public debate to advance their causes, it is true. However, it is almost invariably the case that these advocates making historical arguments are not historians. This painful reality was brought home to the historical profession in 1996-97 by such events as the release of the Final Report of the Royal Commission on Aboriginal Peoples and the debates over public policy issues such as copyright reform and a protocol for research involving humans. It is essential to the future of the discipline and of organisations such as CHA/SHC that historians reassert their role in the processes of researching, interpeting, and utilizing history in public discourse and academic arenas.

Des événements récents laissent penser que l'histoire, en tant que discipline, jouit d'une grande popularité au Canada, mais cette perception est erronée. Il est vrai que pour défendre leurs causes, nombre de personnes, de groupes d'intérêt et même d'institutions ont largement recours à des arguments d'ordre historique dans les débats publics. Toutefois, les intervenants qui manient ces arguments ne sont presque jamais des historiens de profession. Ceux-ci ont pris pleinement conscience de cette pénible réalité en 1996-1997 à l'occasion, entre autres, de la publication du rapport final de la Commission d'enquête sur les peuples autochtones et lors des débats sur les politiques gouvernementales concernant la réforme de la loi sur les droits d'auteur et le code d'éthique de la recherche avec des sujets humains. Il est essentiel pour l'avenir de la discipline et d'organisations telles que la Société historique du Canada que les historiens reprennent la place qui leur incombe lorsqu'il s'agit de recherche en histoire, d'interprétation ou d'utilisation de faits historiques, dans le discours public et dans le milieu universitaire. 


\section{DISTINGUISHED SPEAKER CONFÉRENCIER INVITÉ}

\section{Marginality, Co-Integration and Change: Social History as a Critical Exercise}

\section{GÉRARD BOUCHARD}

In an address delivered as a guest speaker, Gérard Bouchard conveys the theoretical and historiographical considerations which led to the writing of his Quelques arpents d'Amérique. In particular, he presents the concept of family reproduction as a promising tool towards the understanding of the links between micro and macro social phenomena. Thereafter, he traces the limits of the notion of marginality for the study of the multiple economic activities of the Saguenay, which he rejects in favour of co-integration and integration. These concepts allow a consideration of the relation between two systems and for the autonomous dynamic of the society otherwise called a periphery. As illustrations of his global approach, he then offers some conclusions pertaining to contraception, agricultural change and education. He proceeds to identify elements of other North American historiographies of agricultural regions, in Quebec, Canada and the United States, which call for the use of the notion of co-integration. Only once detailed comparisons are made will historians be able to discriminate between the originality of the French Canadian habitant and his "Americanity".

À titre de conférencier invité, Gérard Bouchard livre les considérations théoriques et historiographiques qui ont mené à l'écriture de Quelques arpents d'Amérique. Il s'attache en particulier au concept de reproduction familiale comme outil privilégié de compréhension des liens entre les phénomènes micro et macro sociaux. Il trace ensuite les limites de la notion de marginalité pour l'étude des multiples activités économiques du Saguenay, et la rejette au profit de celles de la co-intégration et de l'intégration. Non seulement ces idéees rendent-elles compte des relations entre deux systèmes et de la multitude des niveaux de causalité, mais elles permettent aussi d'attribuer une dynamique propre à la société autrefois considérée comme périphérique. Il propose en exemple certaines conclusions de son analyse globale de la production agricole, de la contraception et de l'éducation au milieu du vingtième siècle. Il identifie ensuite des éléments de l'histoire agricole canadienne anglaise et de l'histoire d'autres régions du Québec qui ressemblent suffisamment à l'histoire culturelle, économique et sociale du Saguenay pour proposer que soit utilisée, là aussi, l'idée de co-intégration. Ces brèves incursions permettent de penser 
que, de plusieurs façons, l'histoire du Saguenay est marquée par son "Américanité ». Le conférencier termine en appelant une réflexion sur l'originalité de l'Habitant canadien-français qui soit fondée sur la comparaison minutieuse de régions ainsi comprises dans leur complexité.

\section{City Limits: Female Philanthropists and Wet Nurses in Seventeenth-Century Scottish Towns}

\section{GORDON DESBRISAY}

This paper explores the ways in which women contributed to the complex web of negotiations and accommodations out of which the early modern urban community was formed. Drawing on the archives of seventeenth-century Aberdeen and other Scottish cities, it focuses on female philanthropists and unwed wet nurses, women at the top and bottom, the centre and margins of urban society. Rich women founded hospitals for old women and schools for young girls, but these feminist initiatives did not extend to the female guestworkers in their midst: migrant female domestics made pregnant in town had to fend for themselves, and many ended up wet-nursing the children of the rich. Yet in indirect ways they, too, left their mark on urban society. These stories, then, shed fresh light on the complex and sometimes contradictory ways in which early modern women pursued their collective and individual interests under conditions of profound gender inequality.

Le présent essai analyse l'apport des femmes au système complexe de négociations et d'ajustements duquel émergea la communauté urbaine du début de l'époque moderne. Tirant ses sources des archives de la ville d'Aberdeen et d'autres villes écossaises du XVII siècle, l'auteur s'intéresse aux femmes philanthropes et aux nourrices célibataires, aux femmes qui se situaient tant dans le haut que dans le bas de l'échelle sociale, tant au centre qu'en marge de la société urbaine. Les femmes fortunées fondaient des hôpitaux pour les femmes âgées et des écoles pour les jeunes filles, mais les auvres de ces féministes ne s'adressaient pas aux travailleuses de l'extérieur qu'elles embauchaient : les domestiques itinérantes qui se retrouvaient enceintes en ville devaient se débrouiller seules, et nombre d'entre elles finissaient par servir de nourrices aux enfants des riches. Pourtant ces femmes, elles aussi, laissèrent indirectement leurs marques dans la société urbaine. Ainsi, l'étude de ces cas permet de jeter une lumière nouvelle sur les moyens complexes et parfois contradictoires que les femmes du début de l'époque moderne utilisèrent pour poursuivre leur intérêts collectifs et individuels dans des conditions de profonde inégalité sexuelle. 


\section{Irish Convict Transportation and the Reach of the State in Late Hanoverian Britain}

\section{SIMON DEVEREAUX}

The difficulties encountered by English authorities in resuming the regular and effective transportation of convicts overseas between the loss of the original American destination in 1775 and the opening of a penal settlement in New South Wales in 1787 are well known to historians of criminal justice. Far less so is the contemporaneous convict crisis in Ireland. This article considers the practice of convict transportation from Ireland throughout the eighteenth century. In particular, it examines a series of three dramatic incidents of the late 1780 s in which Irish convicts were unscrupulously (though not illegally) abandoned in Cape Breton, Newfoundland and the Leeward Islands. It argues, first, that such practices were not entirely surprising given the great difficulties that had often been experienced in transporting convicts from Ireland even before 1775. It goes on to suggest that the subsequent decision of authorities in London to assume a directive role in the transportation of Irish convicts was informed by changing perceptions of the British state in both its national and imperial dimensions.

Entre la perte en 1775 de la destination américaine originale et l'ouverture d'une colonie pénitentiaire en Nouvelle-Galles du Sud en 1787, les autorités anglaises se heurtèrent à des difficultés lorsqu'elles voulurent reprendre la transportation outre-mer régulière et efficace des prisonniers. Si les historiens du droit criminel connaissent bien ces problèmes, ils en savent par contre beaucoup moins sur la crise des détenus que connut l'Irlande à la même époque. L'article ci-dessous vient combler cette lacune en se penchant sur l'institution de la transportation des prisonniers hors de l'Irlande au XVIII siècle. Il examine plus particulièrement une série de trois incidents dramatiques qui se déroulèrent à la fin des années 1780 et aux cours desquels des détenus irlandais furent abandonnés sans scrupule (mais toutefois pas illégalement) au Cap-Breton, à Terre-Neuve et dans les îles Sous-le-Vent. L'auteur explique d'abord que, dans le contexte de l'époque, de telles pratiques ne devaient pas entièrement surprendre, étant données les grandes difficultés qu'avait souvent posées la transportation des détenus hors de l'Irlande, et ce avant même 1775. Il suggère par la suite que la décision ultérieure de Londres de prendre en main la direction de la transportation des prisonniers irlandais fut dictée par le changement des perceptions que l'État britannique se faisait de ses dimensions tant nationales qu'impériales. 


\section{Évolution organisationnelle et sociale de la milice sédentaire canadienne : le cas du bataillon de Saint-Hyacinthe, 1808-1830}

\section{CHRISTIAN DESSUREAULT ET ROCH LEGAULT}

Cet article propose d'effectuer, de manière conjointe, l'analyse organisationnelle de la milice et l'étude sociale du bataillon de Saint-Hyacinthe au début du XIX ${ }^{e}$ siècle. Cette recherche permet entre autres de vérifier la persistance de cette instance traditionnelle de pouvoir dans la société rurale bas-canadienne. La structure de commandement du bataillon de Saint-Hyacinthe respecte la hiérarchie de cette société rurale. Les officiers de milice disposent de manière générale d'un niveau de fortune et d'une richesse foncière supérieurs. De plus, les liens familiaux constituent un facteur important de cohésion à l'intérieur de l'institution. Au cours de la période étudiée, les nouvelles responsabilités civiles et politiques confiées aux officiers de milice, la présence grandissante des marchands et des membres des professions libérales dans la structure de commandement, ainsi que le resserrement des liens familiaux entre les officiers, sont témoins de la vigueur de cette institution.

The intention of this article is to conduct both an organizational analysis of the militia and a social study of the Saint-Hyacinthe Battalion at the beginning of the 19th century. This research has a number of purposes, among which is to verify the duration of this traditional form of power in the rural society of Lower Canada. The command structure of the Saint-Hyacinthe Battalion follows the hierarchy of the rural society. As a general rule, militia officers have a higher level of disposable income and own extensive properties. In addition, family links constitute an important cohesive factor within the institution. During the course of the period studied, the new civil and political responsibilities entrusted to the militia officers, the growing presence of merchants and professional people in the command structure, as well as the strengthening of family ties among the officers, testify to the vigour of this institution.

\section{The Transportation of Chinese Convicts from Hong Kong, 1844-1858}

\section{CHRISTOPHER MUNN}

Between 1844 and 1858 a total of 576 convicts, nearly all of them Chinese, were transported from Hong Kong to other British colonies. For the government this was a convenient, deterrent and inexpensive punishment in a juris- 
diction troubled by high crime and low conviction rates. For the convicts the experience was a varied one: some served out long sentences with little prospect of return; others rebelled, escaped, or killed themselves. In 1858, when the last destination closed its doors to Hong Kong's transports, the colony was forced back on its own resources: with a prison dangerously overcrowded during a period of war and disorder, it faced a penal crisis similar to that experienced in England 75 years earlier. This article explores the policies, practices and experiences of transportation from early British Hong Kong and links the demise of transportation with controversial revisions of the colony's penal policies in the 1860s.

Entre 1844 et 1858, 576 prisonniers, presque tous des Chinois, furent déportés de Hong Kong vers d'autres colonies britanniques. Pour le gouvernement d'une juridiction affligée d'un taux élevé de criminalité et d'un faible pourcentage de condamnations, ce châtiment était commode, dissuasif et peu cô̂teux. Le destin des prisonniers variait d'un cas à l'autre : certains purgeaient de longues peines sans grand espoir de retour; d'autres se rebellaient, s'évadaient ou se suicidaient. En 1858, quand la dernière destination ferma ses portes aux détenus de Hong Kong, la colonie dut compter sur ses propres ressources : sa prison étant dangereusement surpeuplée à une époque où sévissaient guerre et désordre social, Hong Kong se trouva donc aux prises avec une crise pénitentiaire semblable à celle que l'Angleterre avait vécue 75 ans plus tôt. Le texte présenté ici s'intéresse aux politiques, aux pratiques et aux cas vécus de la transportation au début de la période coloniale britannique à Hong Kong et relie la fin de l'institution de la transportation à la révision controversée des politiques pénales de la colonie dans les années 1860.

\section{Poisoning the Student Mind?: The Student Christian Movement at the University of Toronto, 1920-1965}

\section{CATHERINE GIDNEY}

Historians have documented the interlocking nature of student culture and religious life in nineteenth-century higher education; in contrast, after World War I religion has generally been ignored, or portrayed as disappearing from the academy and broader life. An investigation of the Student Christian Movement, however, suggests that by combining liberal theology with left-wing politics it became an influential religious force on campus well into the twentieth century. Reflecting a fairly homogeneous student population, supported by faculty and the administration, and articulating the temper of the times, the SCM served as the public voice of religion on campus. Only in the 1950s, as 


\section{ABSTRACTS/RÉSUMÉS}

new social phenomena emerged, such as divisions among Protestants, the rise of agnosticism, and the creation of secular political organisations, did the SCM begin to lose its cultural authority on campus.

La complémentarité de la culture étudiante et de la vie religieuse dans l'enseignement supérieur au XIX ${ }^{e}$ siècle a été bien démontrée par les historiens. Par contre, très peu d'études ont été consacrées à la religion après la Première Guerre mondiale et celles qui s'y intéressent soulignent son rôle déclinant dans le cadre universitaire et dans la vie de la population en général. Toutefois, en examinant le Student Christian Movement, on s'aperçoit que ce mouvement, en alliant théologie libérale et politiques de gauche, devint une force religieuse influente sur les campus pendant une bonne partie $d u X X^{e}$ siècle. Traduisant les valeurs d'une population étudiante relativement homogène, approuvé par le corps enseignant et l'administration, et exprimant l'atmosphère de l'époque, le $S C M$ se fit la voix publique de la religion sur les campus. Ce n'est que vers les années 1950 qu'il commença à perdre son ascendant culturel, alors qu'émergeaient de nouveaux phénomènes sociaux, tels que les divisions entre Protestants, la montée de l'agnosticisme et la création d'organisations politiques laïques.

\section{Constructing Community and Consumers: Joseph R. Smallwood's Barrelman Radio Programme}

\section{JEFF A. WEBB}

Under the name "The Barrelman" Joseph R. Smallwood exhibited a unique collection of oral tradition and historical anecdote in radio broadcasts that aired between 1937 and 1943. Smallwood's radio programme fostered Newfoundland nationalism, yet at the same time it undercut that nationalism by encouraging listeners to want a North American consumer lifestyle. As a commercial programme, it advertised the products of the show's sponsor, F.M. $O$ 'Leary, and contained an underlying discourse that reconstructed listeners as consumers. Smallwood's nationalism was not unproblematic either. In the economic crisis of the Depression, Smallwood's tales of heroism and success were used to promote a self-reliant popular culture with the aim of creating a cultural change among Newfoundlanders that would improve their economic performance. Since the Newfoundland state was no longer democratic, his nationalist vision was decentred from the state and built upon a foundation of those qualities of the people that Smallwood wanted to encourage. 
Dans son émission de radio «The Barrelman » diffusée de 1937 à 1943, Joseph $R$. Smallwood présenta à son auditoire un répertoire unique d'anecdotes historiques inspirées de la tradition orale. Son programme raviva le nationalisme terre-neuvien, mais en amenuisa en même temps la portée en incitant les auditeurs à vouloir un style de vie de consommateurs nord-américains. Comme il s'agissait d'une émission commerciale, on y annonçait les produits du commanditaire, F.M. O'Leary, et on y tenait un discours sous-jacent qui reconvertissait les auditeurs en consommateurs. Le nationalisme de Smallwood n'était pas non plus sans poser quelques problèmes. Pendant la crise économique des années 1930, Smallwood se servit des récits d'hérö̈sme et de succès pour promouvoir une culture populaire autosuffisante qui provoquerait chez les Terre-Neuviens un changement culturel propre à améliorer leur performance économique. Puisque l'État de Terre-Neuve n'était plus démocratique, Smallwood ne centra plus sa vision nationaliste sur l'État, mais chercha plutôt à l'ériger sur les qualités mêmes du peuple qu'il voulait encourager.

\section{Polling Consumers: The Rise of Market Research Surveys in Canada, 1929-1941}

\section{DANIEL J. ROBINSON}

Consumer sample surveys, the predecessor of opinion polling, emerged in the late 1920s as a response to the marketing problems of lacklustre demand and inefficient distribution. In conjunction with Dominion Bureau of Statistics marketing data, consumer surveys were conceived and championed as the demandside corollary of rationalised manufacturing methods. By providing quantitative measures of buyer wants and behaviours, they could improve the efficiency and effectiveness of advertising, thus boosting aggregate consumer spending. Chief among the early promoters and practitioners of consumer surveys were advertising agencies, market research firms, and newspaper and magazine publishers. While some US historians of mass marketing have characterised the phenomenon as a democratic leveller of consumption, Canadian consumers, as represented in market surveys, were not a facsimile of the general population. They were disproportionately married and female, urban and English-speaking, and, most of all, drawn from middle-to-upper-income ranks.

Les enquêtes par sondage sur la consommation, précuseurs des sondages d'opinion publique, apparurent vers la fin des années 1920 en réponse aux problèmes de marketing posés par la faiblesse de la demande et par l'inefficacité de la distribution. Menées conjointement avec le programme des données de mise en marché du Bureau fédéral de la statistique, les enquêtes auprès 


\section{ABSTRACTS/RÉSUMÉS}

des consommateurs furent conçues et soutenues pour documenter la demande du marché, un corollaire de la rationalisation des méthodes de fabrication manufacturière. En mesurant quantitativement les comportements et les besoins de l'acheteur, ces études permettaient d'améliorer le rendement et l'efficacité de la publicité, haussant ainsi le total des dépenses des consommateurs. Parmi les premiers et les plus importants promoteurs et utilisateurs d'enquêtes par sondage se trouvent les agences de publicité, les maisons d'études de marché, les journaux et les éditeurs de magazines. Bien que quelques historiens américains spécialistes du marketing de masse aient caractérisé le phénomène de "niveleur» démocratique de la consommation, on ne peut pas appliquer ce raisonnement aux consommateurs canadiens qui, selon les études de marché, n'étaient pas représentatifs de l'ensemble de la population. D'une façon disproportionnée, ces consommateurs étaient des couples, des femmes, des anglophones et des citadins presque tous issus des classes moyennes et supérieures.

\section{Pacifism or Anti-Imperialism?: The CCF Response to the Outbreak of World War II}

\section{JAMES NAYLOR}

Examining the Co-operative Commonwealth Federation's response to the outbreak of World War II, this paper shifts the focus away from J.S. Woodsworth's allegedly "pacifist" refusal to support the war effort. Instead, it explores the context and language of the broader debate among CCFers regarding militarism, fascism and imperialism. Very rarely was this debate framed in pacifist terms. It was axiomatic to the CCF that the twin evils of fascism and war were the products of capitalism and that war among capitalist powers retained an imperialist character. Acquiescing to participation in such a war was not only unprincipled but also undermined the basis upon which a socialist, workingclass identity could be constructed. Once the war was under way, the CCF could hardly deny its initial ambivalence to the war, but chose to restate it in pacifist terms that were less challenging to the Canadian state, the allies, and the war effort.

L'auteur examine ici la position de la Co-operative Commonwealth Federation sur le déclenchement de la Deuxième Guerre mondiale, mais plutôt que de s'en tenir au discours de J.S. Woodsworth qui oppose un refus présumément «pacifiste» à l'effort de guerre, il se tourne vers les membres de la CCF et tente de cerner le contexte et le langage de leurs débats sur les questions plus générales du militarisme, du fascisme et de l'impérialisme. Ces discussions ont très rarement été formulées en termes pacifistes. Pour la CCF, il allait de soi que 
le fascisme et la guerre étaient deux fléaux inhérents au capitalisme et que toute guerre entre puissances capitalistes avait un fond impérialiste. Approuver la participation à une telle guerre, c'était non seulement se montrer peu scrupuleux, mais c'était aussi ébranler les assises de la future identité socialiste et prolétaire. Une fois la guerre enclenchée, la CCF nia à peine son ambivalence initiale face aux hostilités, mais choisit de la réexprimer en des termes pacifistes moins provocateurs pour l'État canadien, les Alliés et l'effort de guerre.

\section{Fishing in the Cold War: Canada, Newfoundland and the International Politics of the Twelve-Mile Fishing Limit, 1958-1969}

\section{MIRIAM WRIGHT}

The intensification of offshore fishing by European trawlers in the northwest Atlantic in the 1950s and 1960s had many repercussions for the Newfoundland fishery. With only a three-mile fishing limit between themselves and the more technologically advanced Europeans, many people involved in the Newfoundland fishery demanded the federal government extend fishing rights to twelve miles from shore. The international debate on the extended fishing rights/territorial waters issue, however, was complicated by its entanglement in Cold War politics. Indeed, the Canadian government's attempts to find a solution in the aftermath of the failed United Nations Law of the Sea Conferences in 1958 and 1960 came face-to-face with the defence agenda of the United States Navy. In such an atmosphere, the Canadian government could do little to protect the resource without risking the wrath of its neighbour and largest trading partner.

L'intensification de la pêche côtière par les chalutiers européens dans le nordouest de l'Atlantique dans les années 1950 et 1960 eut de nombreuses répercussions sur la pêche terre-neuvienne. Comme une limite de pêche de seulement trois milles séparait les Terre-Neuviens des Européens, qui disposaient d'une technologie avancée, de nombreuses personnes travaillant dans les pêcheries terre-neuviennes réclamèrent au gouvernement fédéral qu'il étende leur droit de pêche à douze milles des côtes. Cependant, le débat international sur les droits de pêche étendus et sur les limites des eaux territoriales se compliqua du fait qu'il se télescopa aux politiques de la Guerre froide. En effet, par suite de l'échec des conférences de 1958 et de 1960 sur la Convention des Nations Unies sur le droit de la mer, le gouvernement canadien tenta de trouver des solutions, mais il se heurta aux priorités de défense de la Marine 


\section{ABSTRACTS/RÉSUMÉS}

américaine. Dans un tel contexte, le Canada ne pouvait prendre les mesures appropriées pour protéger ses ressources sans risquer de provoquer la colère de son voisin et plus important partenaire commercial.

\section{Building a Culture of Retirement: Class, Politics and Pensions in Post-World War II Ontario}

\section{JAMES STRUTHERS}

This paper examines four factors which influenced the development of old age pensions in Canada after World War II. The legacy of Canada's original meanstested pension program, the class politics of pension bargaining between business and organized labour on both sides of the border, the policy example of Social Security in the United States, and the key importance of the insurance and investment industry lobby operating through successive Conservative governments in Ontario, are highlighted as critical factors which affected the timing and limited the scope of Canada's public pension system. The residualist design of Old Age Security in 1951 and Ontario's success in gaining a veto over reforms to the Canada Pension Plan in 1965 are singled out as a key factors behind the current vulnerability of Canadian public pensions to fiscal cutbacks compared to the Social Security in the United States.

Le présent texte analyse quatre des facteurs qui ont influencé la mise en place d'un régime de pensions de vieillesse au Canada après la Deuxième Guerre mondiale. Ces facteurs décisifs qui ont déterminé le calendrier d'application du régime de pensions de l'État et qui en ont limité la portée sont les suivants : le legs du premier programme de pensions de vieilesse du pays, fondé sur des enquêtes sur les ressources des bénéficiaires, le jeu des politiques de classe dans les négociations relatives à la pension opposant le monde des affaires à celui de la main-d'auvre syndiquée de chaque côté de la frontière, l'exemple du modèle américain en matière de sécurité sociale, et l'importance majeure du lobby des sociétés d'assurance et d'investissement auprès des gouvernements conservateurs successifs en Ontario. Si les régimes de pensions canadiens sont actuellement plus vulnérables aux compressions budgétaires que les programmes de sécurité sociale des États-Unis, c'est entre autres et surtout parce que le programme d'assistance aux vieillard dans le besoin a été élaboré à partir d'un projet résiduel et parce que l'Ontario a réussi à obtenir en 1965 un droit de veto sur les réformes du régime de pensions du Canada. 